\title{
The Relationship between the Measure and Usage of Social Networking Young People and Globalization of Culture
}

\author{
Shahnaz Hashemi, Mohammad Soltanifar \\ ${ }^{1}$ Assistant professor of Organization for Educational Research \& Planning, Institute of Curricula and educational \\ innovation, Tehran, IRAN, ${ }^{2}$. Associate professor of Islamic Azad University (Science \& Research Branch), \\ Tehran, IRAN
}

\begin{abstract}
Young people use the internet and social networking is growing by the day. This use is common among the educated class, due to the need for scientific information. However, the concept of "globalization" offers the opportunity for developing countries to make use of technical resources and information for developed countries and make efforts to eliminate backwardness in the world today. Globalization may bring temporary losses to some countries, but not a permanent condition.

This research has tried to explain the usage of social networks, either positive or negative effects of media on the path of globalization of culture from View point of young people.

This study is based on survey research methods. This research was a case study population, 201 Ms students are in Social Communication Sciences, Islamic Azad University of Tehran. Cochran's sample size is based on a formula equal to 132 selected students and prospective students of the University of methods that have a tendency to fill out the questionnaire.

Our findings show that the influence of social networks to create a global culture of cyber culture among young people, in other words, Officials and families need to have more control over the use of the excessive youth.

Indiscriminate use of virtual social networks will change the structure of local and national culture and identity and cause the risk of alienation. Young people living away from the real world and the virtual world and are alien to the realities of life.
\end{abstract}

Keywords: Globalization, social networks, culture, internet, youth

\section{Introduction}

One of the newest and yet drastic issue which, nowadays shades on lookout of sociology is globalization. This concept which has not passed two decades somewhat has close relation with global integration-compacting of world-wide communication that McLuhan introduced it by relying on extend of communication facilities. This concept has diverse meanings and long-term effects. In nation and world-wide, globalization would not be restricted to economical boundaries but politically, social and cultural structure will perform a determinant role in future formation of globalization [1].

In a specific meaning, globalization is the most significant heritage which the twenty-first century has taken it from the last social science achievements in twenty century. Indeed, the debate has begun since mid-90s; however we can observe a meaningful progress in this argument [2] \& [3].

In comparison between social-science preoccupation in hundred years ago with modern world and globalization, there are two significant and substantial substitutions in concept area; first, the concept of globalization to universality which is an ordinary thought and second, the distinction between place and time [4].

Gidness suggested that globalization proceeding powerfully and is re-forming our life; however it would be facing varied risks. According to his opinion, although the fundamental process was originated from west and united superiority in united sate it is beneath of globalization [5].

Globalization is a factual and inevitable and human-being is moving to some universal, cultural and political patterns as general identity and on the other hand, micro and local identities are renewing and recovering [6]. 
Gidness in some stages of globalizing mentioned to a concept which called it "reserved colonization". Based on this concept, globalization gives some chances to developing countries to employ developed countries' technical, technological and data resources. Hence put their efforts to eliminate their backwardness and contribute in new modern world. Basd on this idea, however globalization may bring about some contemporary losses, it will not take longer [5].

Globalization is not an absolute and infinitive concept but also is a process with relatively vast meanings which stemmed from diverse trends to globalization. Whenever there are some distinctive and contradictory standpoints, inevitably to define them, we should begin negative implication.

Negative implications include the following issues: globalization due to different fields across world is leading the world uniting the world in fields of cultural, economic and political domains. Globalization does not mean to create universal single-culturalism trends. In the fields of politics, globalization does not mean to nation-state is substituted with superiority power. In field of economy, it does not aim monopoly power and a unite system of economics. Globalization is not an individual process; because, contribution of communication industry, vast of globalization is appearing and eventually globalization does not equivalent internationalization [7].

Internet provides promising facilities for comprehensive globalization. Energetic social groups are capable of utilizing electronic connections for extending international contribution and coalition. Therefore, developing countries' practitioners can readily access to developed countries' expert data base and archives [8].

Forming parallel word behind real world, personal and social behaviors and social relations has been changed substantially. The future world will extend hybrid identities. Shaping up new symbiosis out of national environment is production of entering cyberspace which can be introduced as superseded citizenship, culture and symbiosis. This can cause that the individual separates from indigenous community and joins to his beloved society. Struggles and conflictions due to cyberspaces will extend significantly the conflicted areas, and in next decade we will encounter wide diversity of religious, valuable, scientific, behavioral, identity pluralism. So by strengthening individuality, reversed trends instead of historical trends will be beginning [6].

Chiller [9] stated that data highways and cyberspace would not provide ideal scope of free communications rather it would create a proper market in which by push a click, they would act in time. People who are fascinated about network facilities do not have knowledge of who are supervising the data and can access to data and probably being utilized by whom?

Ibrahimabadi [10] observed that the positive aspect of globalization is cultural pluralism and noted emersion and booming in cultural pluralism in the light of changes which takes into account globalization bring about that different countries attend to diverse culture within their homeland, devolving part of duties to minorities and cultural ethnicities, policy modification, citizenship's right, moving to decentralization and adopting pluralism policies. Ibrahimabadi studied the globalization impacts on national identities and ethnicities in Iran such as sanandajian Kurds and claimed that globalization causes national identities has been probably weakened and reinforced ethnic identity in investigated sample [11]

On the other hand, Babaee [12] believed that globalization process can threat traditional cultures and causes to distribute western values and norms.

\section{Identity Crisis}

Individual possess their own life and identity while their needs to continuity, constancy, differentiation, similarity with community and being excellent and absolute reach to an acceptable stage. Although in a traditional community, some elements such as milieu, time and culture has provided these needs, globalization process may belong traditional identity by disconnecting these consociations, thus appears identity and meaning crisis. In this part, we explain in details these elements.

A. In comparison with milieu, place has a huge capability and sufficiency to provide needs for constancy, differentiation and social solidarity. So globalization process creates identity and meaning crisis with deterritorialization and make frame for social life [13] 
B. Globalization causes that borders become penetrable and raises the cultural encounters therefore enhances human consciousness about other cultural elements. In this situation, believing to a superiority special world and defend it against other cultures would become so complicated. Whenever this traditional identity source begins deteriorating, individuals who are dependent to those sources will become perplexity [14].

C. Globalization process not only makes variety of culture available to others, rather synergize their social references and world views. Hence scarce references about traditional communities which provided conveniently individual's identity needs will be vanished and individual will be inevitably forced to identify with macro and micro social identities [14].

By growing trend utilizing social network, we decide to investigate the effects of WANs on creating virtual cultures between youths. This virtual culture resembles globalization which is main aim. In this study we try to investigate this trend base on youth's view

\subsection{Main Goals}

Recognizing the role of social networks in making youth's culture globalized.

\subsection{Hypothesis}

There is a relationship between Facebook and make youth's culture globalized. There is a relationship between Google and make youth's culture globalized.

There is a relationship between YouTube and make youth's culture globalized.

There is a relationship between Twitter and make youth's culture globalized.

\subsection{Research Methodology}

This study was carried out base on survey studies and questionnaires were prepared to gathering data. Statistical data had been gathered composed of 201 masters of communication science students from Azad University, Tehran Markaz branch. According to Cochran formula, the sample size included 132 students and they were selected among students by chance who intended to fill questionnaires. For analyzing, statistical methods and SPSS software were used.

\subsection{Variables}

Social network and globalization of youth1' culture are independent and dependent variables respectively.

$\checkmark$ Social networks include Google, Facebook, Twitter and YouTube.

$\checkmark$ Items assess world culture included

\subsection{Research Results}

Filling the questionnairies were carried out by 132 individuals included 93 women and 29 men which are $70.5 \%$ women and the rest is men. The youngest person aged 22 and the oldest was 39 years old. The variation range is 17 . The average age is 30 , variance is 16.278 and standard variation is 4.035 . in our study, there is $36.4 \%$ employed people and $63.6 \%$ are unemployed and $69.7 \%$ of samples are single and $30.3 \%$ are married.

From 132, 3.8\% do not use internet at all and 96.25 use internet. Using social network encompassed 82.6 and 17.4 does not access to it.

$57.6 \%$ of 132 individuals filled the questionnaires uses social network about 5-10 hours per week, $9.1 \%$ uses social network about 10-15 hours per week, 2.3\% uses social network about 15-20 hours per week and 12.1\% uses social network about 20-40 hours per week. As results, using 5-10 hours per week has largest population and 15-20 hours stand on the last step. 
TABLE I: using variant networks

\begin{tabular}{|c|c|c|}
\hline Social networks & frequency & Percentage \\
\hline Facebook & 28 & 19.7 \\
\hline Twitter & 15 & 3.8 \\
\hline YouTube & 5 & 1.5 \\
\hline Google & 58 & 3.8 \\
\hline All items & 9 & 1.5 \\
\hline None of them & 7 & .8 \\
\hline Total & 132 & 100 \\
\hline
\end{tabular}

The most access belonged to goggle by $40.2 \%$ and the last is twitter by $0.8 \%$. The most item which is viewed belong to scientific information by $28 \%$ and $0.8 \%$ is the least which belonged to others. Surfing internet just for funs is close to first item with $25.8 \%$.

$47 \%$ of respondents download programs and $42.2 \%$ do not do it. In twitter and YouTube, $65.9 \%$ of respondents download programs and $6.1 \%$ just upload.

TABLE II: Respondent's opinion about word culture items in order of priority

\begin{tabular}{|c|c|c|c|c|c|c|c|}
\hline World culture & $\begin{array}{c}\text { Absolutely } \\
\text { disagree }\end{array}$ & disagree & $\begin{array}{c}\text { No- } \\
\text { opinion } \\
\end{array}$ & agree & $\begin{array}{c}\text { Completely } \\
\text { agree } \\
\end{array}$ & No answer & $\begin{array}{l}\text { Average } \\
\text { from } 5\end{array}$ \\
\hline $\begin{array}{l}\text { Everybody should choose } \\
\text { his identity }\end{array}$ & $\begin{array}{c}7 \\
5 / 3\end{array}$ & 0 & $\begin{array}{l}9 \\
6 / 8\end{array}$ & $\begin{array}{c}57 \\
43 / 2 \\
\end{array}$ & $\begin{array}{c}54 \\
40 / 9 \\
\end{array}$ & $\begin{array}{c}5 \\
3 / 8 \\
\end{array}$ & $1 / 7$ \\
\hline $\begin{array}{l}\text { I am interested to be with } \\
\text { my friends instead my } \\
\text { family }\end{array}$ & $\begin{array}{c}9 \\
6 / 8\end{array}$ & $\begin{array}{c}4 \\
3 / 0\end{array}$ & $\begin{array}{l}15 \\
11 / 4\end{array}$ & $\begin{array}{c}52 \\
39 / 4\end{array}$ & $\begin{array}{c}39 \\
29 / 5\end{array}$ & $\begin{array}{l}13 \\
9 / 8\end{array}$ & $1 / 8$ \\
\hline $\begin{array}{l}\text { I select my wear mode near } \\
\text { to world class }\end{array}$ & $\begin{array}{c}9 \\
6 / 8\end{array}$ & $\begin{array}{c}7 \\
5 / 3\end{array}$ & $\begin{array}{l}6 \\
4 / 5\end{array}$ & $\begin{array}{c}67 \\
50 / 8\end{array}$ & $\begin{array}{c}31 \\
23 / 5 \\
\end{array}$ & $\begin{array}{r}12 \\
9 / 1\end{array}$ & $1 / 9$ \\
\hline $\begin{array}{l}\text { I try to approach my } \\
\text { fashion mod to world class }\end{array}$ & $\begin{array}{c}20 \\
15 / 2 \\
\end{array}$ & $\begin{array}{c}5 \\
3 / 8 \\
\end{array}$ & $\begin{array}{l}9 \\
6 / 8 \\
\end{array}$ & $\begin{array}{c}52 \\
39 / 4 \\
\end{array}$ & $\begin{array}{l}37 \\
28 \\
\end{array}$ & $\begin{array}{c}9 \\
6 / 8 \\
\end{array}$ & $2 / 18$ \\
\hline $\begin{array}{l}\text { Speaking in English } \\
\text { language for } \\
\text { communication is sufficient }\end{array}$ & $\begin{array}{c}9 \\
6 / 8\end{array}$ & $\begin{array}{c}23 \\
17 / 4\end{array}$ & $\begin{array}{l}11 \\
8 / 3\end{array}$ & $\begin{array}{c}61 \\
46 / 2\end{array}$ & $\begin{array}{c}18 \\
13 / 6\end{array}$ & $\begin{array}{c}10 \\
7 / 6\end{array}$ & $2 / 4$ \\
\hline $\begin{array}{l}\text { Youth needs their family } \\
\text { supports to make family }\end{array}$ & $\begin{array}{c}14 \\
7 / 6 \\
\end{array}$ & $\begin{array}{c}26 \\
10 / 6 \\
\end{array}$ & $\begin{array}{l}17 \\
12 / 9\end{array}$ & $\begin{array}{c}55 \\
41 / 7 \\
\end{array}$ & $\begin{array}{c}10 \\
7 / 6 \\
\end{array}$ & $\begin{array}{c}10 \\
7 / 6 \\
\end{array}$ & $2 / 6$ \\
\hline $\begin{array}{l}\text { I enjoy fast food and } \\
\text { western food more }\end{array}$ & $\begin{array}{r}10 \\
7 / 6 \\
\end{array}$ & $\begin{array}{c}22 \\
16 / 7 \\
\end{array}$ & $\begin{array}{l}32 \\
24 / 2 \\
\end{array}$ & $\begin{array}{c}58 \\
43 / 9\end{array}$ & $\begin{array}{c}2 \\
1 / 5 \\
\end{array}$ & $\begin{array}{c}8 \\
6 / 1 \\
\end{array}$ & $2 / 7$ \\
\hline $\begin{array}{l}\text { I prefer to choose a work } \\
\text { which is permanent and not } \\
\text { temporary or project } \\
\text { work(entrepreneurship) }\end{array}$ & $\begin{array}{c}23 \\
17 / 4\end{array}$ & $\begin{array}{c}16 \\
10 / 12\end{array}$ & $\begin{array}{l}42 \\
31 / 8\end{array}$ & $\begin{array}{c}31 \\
23 / 5\end{array}$ & $\begin{array}{c}14 \\
10 / 6\end{array}$ & $\begin{array}{c}6 \\
4 / 5\end{array}$ & $2 / 8$ \\
\hline $\begin{array}{l}\text { It is sufficient to have one } \\
\text { pattern for people in world }\end{array}$ & $\begin{array}{c}52 \\
39 / 4\end{array}$ & $\begin{array}{c}32 \\
24 / 2\end{array}$ & $\begin{array}{l}17 \\
12 / 9\end{array}$ & $\begin{array}{l}16 \\
/ 12 \\
10\end{array}$ & $\begin{array}{l}10 \\
7 / 6\end{array}$ & $\begin{array}{c}5 \\
3 / 8\end{array}$ & $3 / 64$ \\
\hline
\end{tabular}

Whatever the average approaches to 5, respondents are beyond from world culture, that is, against it. We put our criteria in 3 and items which are less than 2.5, it means they are near to world culture views. Hence maximum average about global harmonization for culture is 3.64 and this item reveals that the most respondents agreed cultural diversity and after it, there is there is traditional affairs strategies which mentioned that 
respondents tend to work in a predetermined and official businesses and not prefer modern entrepreneurship. Fast food's average is the next by 2.7 and finally respondents tend to get their family's support to become independent.

TABLE III: One- sample Test

\begin{tabular}{|c|c|c|c|c|c|c|}
\hline \multicolumn{7}{|c|}{ Test value $=2.75$} \\
\hline \multirow[t]{2}{*}{$\begin{array}{l}\text { Globalization } \\
\text { culture }\end{array}$} & \multicolumn{2}{|c|}{$\begin{array}{l}\% 95 \text { Confidence Interval of the } \\
\text { Difference }\end{array}$} & \multirow[t]{2}{*}{$\mathrm{t}$} & \multirow[t]{2}{*}{$\mathrm{df}$} & \multirow[t]{2}{*}{$\operatorname{Sig}(2$ tailed) } & \multirow[t]{2}{*}{$\begin{array}{l}\text { Mean } \\
\text { Difference }\end{array}$} \\
\hline & Upper & Lower & & & & \\
\hline Face book & 1.70 & 1.77 & 103.849 & 132 & 0.000 & 1.732 \\
\hline Google & 1.53 & 1.66 & 48.150 & 132 & 0.000 & 1.596 \\
\hline YouTube & 0.89 & 1.34 & 9.887 & 132 & 0.000 & 1.113 \\
\hline twitter & 0.97 & 1.51 & 35.647 & 132 & 0.000 & 1.256 \\
\hline
\end{tabular}

The rest of items due to close to 2.5 and lower that, it means that there is a tendency to world culture which in this survey the greatest trend is choosing identity by own with 1.7. Therefore people can choose new identity out of national culture and then interaction with friends and. Although in Iran the tendency is to family. The average of fashion mode and appearance base on worldwide modes is 1.9 and 2.8 respectively and respondents accepted English language as world language (2.4).

Results exhibit that some changes to globalization which can be efficient and productive such as entrepreneurship and financial independence for youth were not paid attention but some extent such as national identity ( traditional view base on homeland), importance of family and interaction with family has being changed.

It is noteworthy that fashion mode and appearance among Iranian youths that are adopted from western modes has not restricted to new media like social networks rather it comes back to western music and film which were brought to Iran some decades ago.

As it can be observed, in table 3, the test has 0.000 in $\operatorname{sig}(2$ tailed), that states there is significant relationship between using Facebook, Google, YouTube and twitter with youth's culture. Therefore we can conclude that the study hypothesis is confirmed.

\subsection{Suggestions}

According to study's results, the most effective solution to preserve to social network's aims is to notify youths about the fundamental and underlying goals and contents of such social networks, so we can educate youth to use them in an advantageous way. Undoubtedly, these networks provide some fortunes while they are applied for instance, modifying national culture. Of course, certainly, all of national cultures are not suitable for new modern conditions and hence some changes should be performed, so there are profitable solutions to enhance the country likes entrepreneurship which is an outstanding point for industrial and modern countries. Cyberspace can provide an appropriate basis for economy and improving the rate of production so we can utilize it efficiently.

Results indicate that some youths prefer to choose their identity independently, so we can make some documentary films about Iranian who are living overseas. Hereby we can explain the advantages and disadvantages of choosing new identity. Hence by watching such films youths can choose their identity consciously.

According to results, most of young people prefer to spend their leisure times with their friends. Suggested that to prevent family's separations, parents allocate times for gathering the member of family or provide a convenient and charming atmosphere for youth, hence it can enhance the family interaction.

Since youth are interested to wear western clothes, it can be concluded that clothing industries in Iran is not dynamic and active, so in next step we should get assist from movie maker and celebrates. 


\section{References}

[1] Tavvassoli, , GHo. Investigate the dominant discourses of globalization, a social sciences, No. 27, pp. 179-157. 2006.

[2] Robinson, William. Promoting Polyarchy: Globalization, U.S Intervention and Hegoemony (Cambridge: Cambridge University Press), 1996. http://dx.doi.org/10.1017/CBO9780511559129

[3] Inni, O. A Sociedade Global. Rio de Janiro, Brsileria, 1992.

[4] Gidness, A. Consequences of Modernity, translated by M. Triad, Tehran: Publication Markaz, 1998.

[5] Gidness, A. Abandoned world, discourses on global integration, translation A. Saidi, Tehran: publications of elmo adab, 2000.

[6] Tavassoli, GHo. \& Ghasemi, Y. collective identity and globalization, a social sciences, No. 24, pp. 26-1. 2004.

[7] Ameli, SR. Globalization: Concepts and theories, Organon Journal, 2004, No. 24, PP1-66.

[8] Boosaloes. Cyber Imperialism and World Affairs in New Age Electronics, translated Alavi, Parviz, Tehran: Sanieh, 2006.

[9] Chiller, H. The media and the American Empire, translator Ahmad Myrabdyny, Tehran: 1998.

[10] Ibrahimabadi, Gh.. Cultural Pluralism in the era of globalization and the transformation of elite political culture in Iran, MA thesis, Supervisor: doctor Wahid Sinai, 2005.

[11] Khalili Ardekani, MA. The impact of globalization on national identity and ethnic identity (case study, the Kurdish city of Sanandaj) PhD thesis, Supervisor: S. Myd oven, 2010.

[12] Babaee, M. Globalization, global culture and cultural deviant, MSc Thesis, Supervisor: Seyyed Hossein Srajzadh, 2010.

[13] Tomlinson, John. Globalization and Culture ,Research Seminar Series Paper at University Of Notingham Ningbo. 2006.

[14] Golmohammadi,A. "Globalization of Culture, Identity", Tehran: Nshrny, 2007. 